competent cells by antigen, or antigen derivatives, in inducing the change of small lymphocyte to pyrininophil stem cells, and the initiation of germinal centres or of plasma cell clones producing antibody. Present points of difficulty are related to the generation of the essentially unlimited range of immunological patterns by genetic (or somatic-genetic) processes; the range of potential immune reactivity of a lymphoid stem cell, and the possibility of transfer of genetic (immunological) information from one cell line to another. The essential modification of the original theory accepts the existence of frequent somatic mutation in all body cell lines at all periods of life and underlines the great significance of minor genetic change, possibly involving no more than the substitution of one amino-acid for another, in relation to the modern picture of $\gamma$-globulin structure. Equally we must accept as befor the continuance of selective processes throughout life, both negative selection involving destruction or inhibition of physiologically immature cells reacting with antigen in relatively high concentration and positive selection for proliferation and antibody production following contact with antigen under other circumstances.

\section{Woolgorong Stony Meteorite}

Numerous fragments of a stony meteorite were recovered from Woolgorong Station, north-east of Wullewa, in Western Australia, approximately 300 miles north of Perth, in 1961. This find almost certainly represents a possible fall noted in this locality in December 1960. A. double report was heard at the time, but G. J. H. McCall and P. M. Jeffrey, writing in the Journal of the Royal Society of Western Australia (Vol. 47), consider that this does not necessarily imply a multiple fall, since phenomena of this kind are generally attributed to compression wave effects in the atmosphere. The meteorite is a veined and brecciated, grey hypersthene-olivine chondrite, Prior's class III, and shows evidence of pronounced recrystallization. Recovery of fragments from shallow burial in the soil, and from the surface, has allowed a confident reconstruction to be made. There is evidence that it had an aerodynamically stable form under conditions of atmospheric entry, since surface patterns and the distribution of thickened and thinned fusion-crust reveal a distinct orientation. Such orientation supports the idea that this was a single fall, complicated only by fragmentation at or near the point of impact.

Microscopic investigation has revealed considerable structural variation, some areas revealing well-formed, though recrystallized, chondrules. Others show almost complete recrystallization to a granular aggregate of polysomatic and larger fractured grains. In these areas of recrystallization the chondrular structure is only vaguely defined. Chemical tests, etch-tests, X-ray diffraction examinations and two full chemical analyses have been carried out, and the minerals determined include kamacite, iron sulphide (troilite?), olivine (chrysolitehyalosiderite), orthopyroxene, oligoclase, and possibly a ealcium silicate (rankinite?).

\section{University News :}

Aberdeen

THE following appointments to lectureships have been announced: Dr. W. Welsh (geology); Dr. M. N. Court (soil science).

Leeds

THF following appointments to lectureships have been announced: C. R. Abbott (pathology, with special reference to hæmatology); Dr. J. W. Taylor (gas engineering and general fuel science).

London

Dr. John Anderson, reader in medicine at King's College Hospital Medical School, has been appointed to the chair of medicine tenable at that school. Dr. P.N.
Rowe, principal scientific officer in Chemical Engineering Division, Atomie Energy Research Establishment, Harwell, has been appointed to the Ramsay Memorial chair of chemical engineering tenable at University College from October 1. Dr. Kenneth Smith, of the Argonne Laboratory, has been appointed to the readership in mathematics tenable at Royal Holloway College.

Sussex

THE prospectus for 1964-65 of the University of Sussex gives particulars of the introduction of majors in philosophy in the School of African and Asian Studies; experimental psychology in the School of Biological Sciences; and social psychology in the School of Social Studies. Decisions regarding all three were taken too late for inclusion in the Handbook of the Universities Central Council on Admissions.

\section{Eclipse of the Moon, December 19}

There will be a total eclipse of the Moon on December 19, visible at Greenwich. The circumstances are:

$\begin{array}{lc}\text { Moon enters penumbra } & \text { Dec. } 19 \mathrm{~d} \text { 00h } 01 \mathrm{~m} \text { v.r. } \\ \text { Moon enters umbra } & 19 \mathrm{~d} 00 \mathrm{~h} 59 \mathrm{~m} \\ \text { Total ecitpse begins } & 19 \mathrm{~d} 02 \mathrm{~h} 07 \mathrm{~m} \\ \text { Mid-eclipse } & 19 \mathrm{~d} 02 \mathrm{~h} 37 \mathrm{~m} \\ \text { Total eclipse ends } & 19 \mathrm{~d} 03 \mathrm{~h} 07 \mathrm{~m} \\ \text { Moon leaves umbra } & 19 \mathrm{~d} 04 \mathrm{~h} 15 \mathrm{~m} \\ \text { Moon leaves penumbra } & 19 \mathrm{~d} 05 \mathrm{~h} 14 \mathrm{~m} \\ \text { Magnitude of eclipse } & 1.18\end{array}$

\section{Announcements}

Dr. E. J. Denton, senior principal scientific officer at the Laboratory of the Marine Biological Association at Plymouth, has been appointed to a Royal Society research professorship at the University of Bristol. Dr. Denton, who took up his appointment as from October 1, 1964, will be attached to the University of Bristol but will continue to carry out most of his research work at the Plymouth Laboratory. Dr. Denton is distinguished for his contributions to the physiology of marine animals, in particular of their visual processes and maintenance of buoyancy.

THE Association of Commonwealth Universities has published, under the title United Kingdom Postgraduate Awards, 1964-66, information on such awards in a form suitable for quick reference. It does not include awards open to graduates of only one university, or those restricted to the academic staff of a single institution. A short list of awards tenable outside the United Kingdom by graduates of the United Kingdom is also included, and there are subject indexes to both lists, as well as an index to names.

A symposium on "Crustacea", under the auspices of the Marine Biological Association of India, will be held at Cochin during the second week of January. Further information can be obtained from the Convener of the symposium, Marine Biological Association of India, Marine Fisheries P.O., Mandapam Camp.

A symposium on "Morphogenesis and Differentiation in Relation to Cellular Fine Structure", arranged by the British Biophysical Society, will be held at the Imperial College of Science and Technology, London, during January 8-9. Further information can be obtained from Prof. R. E. Burge, Physics Department, Queen Elizabeth College, Campden Hill Road, London, W.8.

A JoINT meeting of the Biochemical Society and the Association of Clinical Biochemists will be held in Leeds during January 7-8. Colloquia on "Vitamin $B_{6}$ in Metabolism" and "Some A.spects of the Biochemistry of Protein and Peptide Hormones" will be held during the meeting. Further information can be obtained from the Meetings Secretary, Biochemical Society, 20 Park Crescent, London, W.1. 